\title{
Abnormalities of digestive tract innervation in rat fetus treated with ethylenethiourea ${ }^{1}$
}

\author{
Anomalias da inervação do trato digestório de fetos \\ de ratas expostas à etilenotioureia
}

\begin{abstract}
Sidney Pereira Pinto Lemos ${ }^{\mathrm{I}}$, José Luiz Martins ${ }^{\mathrm{II}}$, Patrícia Veruska Ribeiro Barbosa Lemos ${ }^{\mathrm{III}}$, Silvio Romero Gonçalves e Silva ${ }^{\mathrm{IV}}$, Fernando Leandro dos Santosv, Valdemiro Amaro da Silva JúniorvI

${ }^{I}$ MS, Research and Surgery Program, Federal University of Sao Paulo (UNIFESP). Assistant Professor, Pediatric Surgery, UNIVASF, Brazil. Concepcion, design, and scientific content of the study, surgical procedures, analysis and interpretation of data, manuscript writing.

IIPhD, Full Professor, Pediatric Surgery Division, Department of Surgery, UNIFESP, Sao Paulo, Brazil. Manuscript writing, critical revision.

IIIMS, Medicine Department, UNIVASF, Brazil. Involved in surgical procedures.

${ }^{\mathrm{IV}} \mathrm{MS}$, Nursing Department, UNIVASF, Brazil. Involved in surgical procedures.

${ }^{v} \mathrm{PhD}$, Associate Professor, Department of Veterinary Medicine, Federal Rural University, Pernambuco, Brazil. Histological and immunohistochemical analysis.

VIPhD, Associate Professor, Department of Animal Morphology and Physiology, Federal Rural University, Pernambuco, Brazil. Histological and immunohistochemical analysis.
\end{abstract}

\section{ABSTRACT}

PURPOSE: The pathophysiology of abnormalities associated with myenteric plexus lesions remains imperfectly understood. Such abnormalities have been correlated with subocclusive intestinal conditions in children with Hirschsprung's disease, cases of chronic constipation and, postoperatively, in cases of anorectal anomalies. This study evaluated abnormalities of the myenteric plexus in fetus from female rats that received ethylenethiourea.

METHODS: Female rats were exposed to ethylenethiourea on the $11^{\text {th }}$ day of pregnancy (experimental group) or to $0.9 \%$ physiological solution (control group). Abnormalities were only found in the experimental group. The digestive tract muscle layer was analyzed morphometrically and changes to the frequencies of nerve plexus cells and interstitial cells of Cajal were evaluated, using hematoxylineosin, S-100 protein, neuron-specific enolase and C-Kit, respectively.

RESULTS: Muscle and skeletal abnormalities were observed in $100 \%$, anorectal anomalies in $86 \%$, absent tail in $71 \%$, short tail in $29 \%$, duodenal atresia in 5\%, esophageal atresia in 5\% and persistent omphalomesenteric duct in 5\%. Histopathological analysis showed a thinner muscle layer associated with lower frequencies of ganglion cells and interstitial cells of Cajal, in all gastrointestinal tract.

CONCLUSION: Severe nerve plexus abnormalities associated with muscle layer atrophy were observed throughout the gastrointestinal tract in newborn rats exposed to ethylenethiourea.

Key words: Ethylenethiourea. Myenteric Plexus. Digestive System. Hirschsprung Disease. Fetus. Rats.

\section{RESUMO}

OBJETIVO: As anomalias associadas a lesões dos plexos mioentéricos permanecem sem plena compreensão da sua fisiopatologia. Alterações nos plexos nervosos têm sido correlacionadas com quadros suboclusivos intestinais em crianças portadoras de doença de Hirschsprung, em constipação crônica e no pós-operatório de anomalias anorretais. Este estudo avaliou as anomalias do plexo mioentérico em fetos de ratos fêmea que ingeriram etilenotioureia (ETU).

MÉTODOS: Ratos fêmea foram expostos no $11^{\circ}$ dia de gestação a ETU $1 \%$ no Grupo Experimento e a solução fisiológica $0,9 \%$ no Grupo Controle. Foram observadas anomalias apenas no Grupo experimento, sendo realizada morfometria da camada muscular e avaliadas alterações da frequência celular nos gânglios do plexo mioentérico e nas células intersticiais de Cajal (CIC) utilizando hematoxilina-eosina, P S-100, Enolase Neurônio Específica e C-KIT.

RESULTADOS: Foram observadas anomalias musculoesqueléticas (100\%), anorretais (86\%), ausência de cauda (71\%), cauda curta (29\%), atresia duodenal (5\%), atresia esofágica (5\%) e conduto onfalomesentérico persistente (5\%). A análise histopatológica mostrou adelgaçamento da camada muscular associada às alterações da frequência das células ganglionares e das CIC em todos os segmentos do trato gastrointestinal.

CONCLUSÃO: Foram observadas alterações graves nos plexos nervosos associadas ao adelgaçamento da camada muscular de todo o trato gastrointestinal nos fetos expostos a ETU.

Descritores: Etilenotiouréia. Plexo Mientérico. Sistema Digestório. Doença de Hirschsprung. Feto. Ratos. 


\section{Introduction}

Anomalies of intestinal nervous plexus, including Hirschsprung's disease and dysganglionosis are related to defects associated with abnormal migration of the neuroblasts ${ }^{1}$, but for such anomalies the explanation for the pathophysiology and embryological remains imperfectly understood ${ }^{2}$.

This diffuse reduction in the number of ganglion cells along the colon is often seen in chronic constipation, so this type of disease can be considered as a possible reason for chronic idiopathic constipation ${ }^{3}$.

This group of diseases affects social and productive life by intervening in the planning and economy of the health system, as well as increased costs and productive force in the country ${ }^{4}$.

These abnormalities have been correlated with obstructive or subocclusive intestinal conditions that are unrelated to tumors, in cases of children with Hirschsprung's disease, cases of idiopathic chronic constipation ${ }^{5}$ and, postoperatively, cases of anorectal anomalies. In particular they have been correlated with cases of low anorectal anomalies that present a good prognosis regarding fecal incontinence but frequently evolve with constipation ${ }^{6}$.

Most of the researches using ethylenethiourea for evaluations of anorectal anomaly are directed to changes in the pelvic region ${ }^{7}$ not including the changes of the small intestine.

With the need to expand the knowledge of dysganglionosis, experimental models have been created over the years to study these diseases, but the relationship between changes in the small intestine and anomalies of myenteric plexus remain unclear.

The improving of the knowledge about the chronic diseases such as constipations and dysplasia of the myenteric plexus, is a great importance for clinical practice, needing a more comprehensive assessment.

With the need of better understanding about the changes of the myenteric plexus in the small intestine in fetuses with anorectal anomalies, this study evaluated changes in the myenteric plexus throughout the gastrointestinal tract induced by ingestion of ETU and the alteration that occurred concurrently in the muscle wall bowel.

\section{Methods}

This study was approved by the Ethics Committees of the Federal University of Sao Paulo and the Federal University of San Francisco Valley.

A randomized laboratory trial was conducted using female Wistar rats from the animal colony of Federal University of San Francisco Valley. On the $11^{\text {th }}$ day of pregnancy, by means of gavage, the experimental group was administered 1\% ETU at a dose of $125 \mathrm{mg} / \mathrm{kg}(12.5 \mathrm{ml} / \mathrm{kg})$ and the control group was administered $0.9 \%$ physiological solution at a volume of $12.5 \mathrm{ml} /$ $\mathrm{kg}^{8}$.

On the $20^{\text {th }}$ day of pregnancy, cesarean section was performed under dissociative anesthesia consisting of xylazine hydrochloride $(3 \mathrm{mg} / \mathrm{kg})$ in association with ketamine hydrochloride $(50 \mathrm{mg} / \mathrm{kg})$. Analgesia consisting of tramadol hydrochloride at a dose of $2 \mathrm{mg} / \mathrm{kg}$ was provided.

After the fetuses had been removed, the rats were sacrificed by deepening the anesthesia.

The fetus were weighed and evaluated macroscopically with the aid of a stereoscope at a magnification of 40X. Any abnormalities present externally or in the digestive tract organs were identified and records. The organs were removed for histological and immunohistochemical evaluations.

The experimental and control groups were subdivided according to the segment of the digestive tract, into experimental and control subgroups for the esophagus and stomach, small intestine and rectum.

After slide preparation using the hematoxylin-eosin staining technique, histological and morphometric analysis was performed under an optical microscope. The method of Blennerhassett et al. ${ }^{9}$ was adapted and used for analyzing the thickness of the muscle layer.

Cross-sectional areas of the gastrointestinal tract were randomly photographed in the segments of the esophagus, stomach, small intestine and rectum of each animal, using a Samsung CCD color video camera coupled to an optical microscope with a $4 \mathrm{X}$ objective lens to record the muscle areas. The final enlargements were $600 \mathrm{X}$.

The cross-sections were measured using ten randomly chosen regions in the selected segments of the esophagus and stomach, small intestine and rectum of each animal, and come up with the average of these measurements.

Immunohistochemical analysis was carried out with the aims of evaluating changes to the frequencies of ganglion cells, using S-100 protein and neuron-specific enolase, and evaluating the ICCs, using C-kit antibodies (CD-117).

To determine the changes to the frequencies of ICCs and ganglion cells, an adaptation of the methodology described by Wedel et al. ${ }^{10}$ was used. In this, cell counts were obtained within the areas that had been measured using the Samsung CCD color video camera coupled to the optical microscope, and the number 
of cells was divided by the area in square millimeters. Five fields were examined at a magnification of $10 \mathrm{X}$ to measure the area, and the ganglion cells were identified at a magnification of $1000 \mathrm{X}$ for identification of ganglion cells and obtaining cell counts observed inside the measured areas and dividing by the number of cells per millimeter square area.

The analyses on the thickness measurements of the muscle layer and on the changes to the frequencies of ICCs and ganglion cells were performed using the Image-Pro Plus 4.0 image analysis system.

The evaluation of muscular layer's thickness of the gastrointestinal tract was performed by comparing similar segments of the intestine in the experimental group with the control group where the areas of the myenteric plexus were altered and not altered, respectively, and the different intestinal segments in each fetus in the same group were also evaluated.

The data obtained were expressed as mean values for each group and statistical comparisons between the different groups were performed using the Kruskal-Wallis test. The significance level was set at $5 \%$ and the analyses were performed using the EXStat module of Excel 2007.

\section{Results}

Thirty-two newborn rats were evaluated: 21 in the experimental group and 11 in the control group. None of the 11 newborn rats in the control group presented any abnormalities. On the other hand, the 21 newborn rats in the experimental group presented a variety of abnormalities in the gastrointestinal tract, musculoskeletal system and spine.

Musculoskeletal abnormalities were observed in 100\% of the fetus rats in the experimental group. These included rib deformities, short thoracic limbs, absence of toes and incomplete formation of the pelvic limb, with severe hip lesions.

Spinal abnormalities were seen in $100 \%$ of the cases, and these were expressed as abnormalities of the tail. Fifteen of the 21 newborn rats $(71 \%)$ were tailless, while the tail was short or vestigial in the other six rats $(29 \%)$. No cases of rachischisis were observed.

We found anorectal abnormalities in 18 of the 21 fetuses $(86 \%)$, persistence of the omphalomesenteric duct in one $(5 \%)$, esophageal atresia in one $(5 \%)$ and duodenal atresia in one $(5 \%)$.

\section{Histological evaluation using hematoxylin-eosin}

In the experimental group animals, the esophagus, stomach, small intestine, large intestine and rectum all presented nerve plexus abnormalities characterized by absence or necrosis of the ganglion cells.

The muscle layers of the wall on the entire gastrointestinal tract were presented thinner, and the more severe the degree of lesion in the myenteric plexus was, the bigger was the lesion in the muscle (Figure 1).
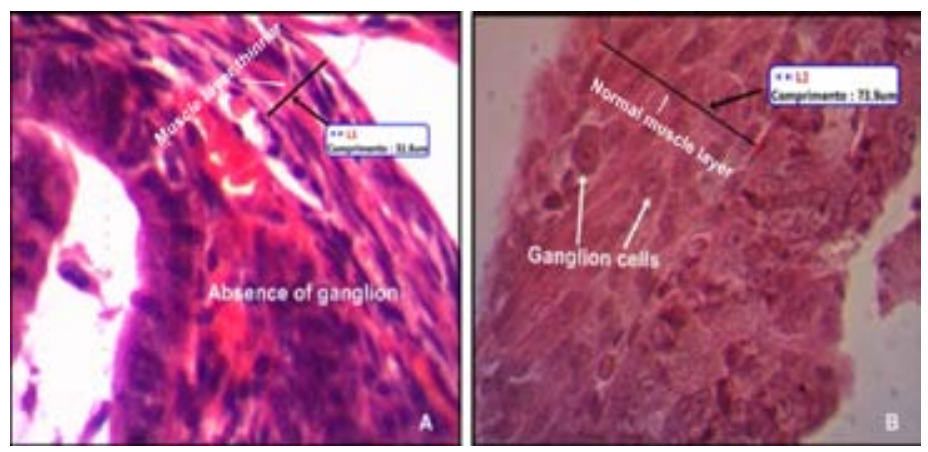

FIGURE 1 - Photomicrograph of cross-section through small intestine of fetus rats showing: A - Thinner muscular layer with absence of ganglion cells in the experimental group, B - Normal intestinal muscle layer with ganglion cells in Auerbach's plexus in the control group. Hematoxylineosin staining; Objective lens 40X.

\section{Morphometry of the muscle layer}

Morphometry on the musculature showed that the muscle layer had become thinner in all segments of the digestive tract. The control subgroup for the esophagus and stomach presented an average of $54.9 \mu \mathrm{m}$, while the average in the experimental subgroup was $26.1 \mu \mathrm{m}$ (Figure 2).

The segments of the small intestine in the experimental group also showed a reduction in thickness in relation to the control group (average of $37.9 \mu \mathrm{m}$ and $20.1 \mu \mathrm{m}$, respectively). A similar relationship was observed in the rectum subgroups, such that the average for the control group was $47.4 \mu \mathrm{m}$, while the average for the experimental group was $20.3 \mu \mathrm{m}$ (Table 1). 
TABLE 1 - Average muscle layer thickness and frequencies of ganglion cells and interstitial cells of Cajal (ICCs).

\begin{tabular}{ccccccc}
\hline & Groups & Experimental & Control & Averages \\
\hline $\begin{array}{c}\text { Segments } \\
\text { of digestive tract }\end{array}$ & $\begin{array}{c}\text { Muscle } \\
\text { layer } \\
\text { thickness } \\
(\text { micrometer })\end{array}$ & $\begin{array}{c}\text { Averages } \\
\text { of ganglion cells } \\
\left(\text { Cells } / \mathrm{mm}^{2}\right)\end{array}$ & $\begin{array}{c}\text { Frequency } \\
\text { of Cajal } \\
\text { cells } \\
\left(\text { Cells } / \mathrm{mm}^{2}\right)\end{array}$ & $\begin{array}{c}\text { Muscle } \\
\text { layer } \\
\text { thickness } \\
(\text { micrometer })\end{array}$ & $\begin{array}{c}\text { Frequency } \\
\text { of ganglion cells } \\
\left(\mathrm{Cells}_{\mathrm{s}} / \mathrm{mm}^{2}\right)\end{array}$ & $\begin{array}{c}\text { Frequency } \\
\text { of Cells } \\
\text { of Cajal } \\
\left(\mathrm{Cells}^{2} / \mathrm{mm}^{2}\right)\end{array}$ \\
\hline $\begin{array}{c}\text { Esophagus and } \\
\text { stomach }\end{array}$ & $26.1( \pm 9.2)$ & $14.6( \pm 2.2)$ & $9.7( \pm 1.1)$ & $54.9( \pm 13.8)$ & $23.9( \pm 2.9)$ & $17.5( \pm 2.9)$ \\
\hline Small intestine & $20.1( \pm 4.7)$ & $12.9( \pm 1.4)$ & $8.6( \pm 1.1)$ & $37.9( \pm 8.9)$ & $21.3( \pm 1.2)$ & $18.6( \pm 1.8)$ \\
\hline Retum & $20.3( \pm 4.7)$ & $13.4( \pm 4.1)$ & $8.2( \pm 0.9)$ & $47.4( \pm 11.8)$ & $21.9( \pm 2.3)$ & $21.1( \pm 2.4)$ \\
\hline
\end{tabular}

The data, presented as average \pm standard deviations, showed that there was a statistically significant difference between the control and experimental groups $(\mathrm{P}<0.01)$.

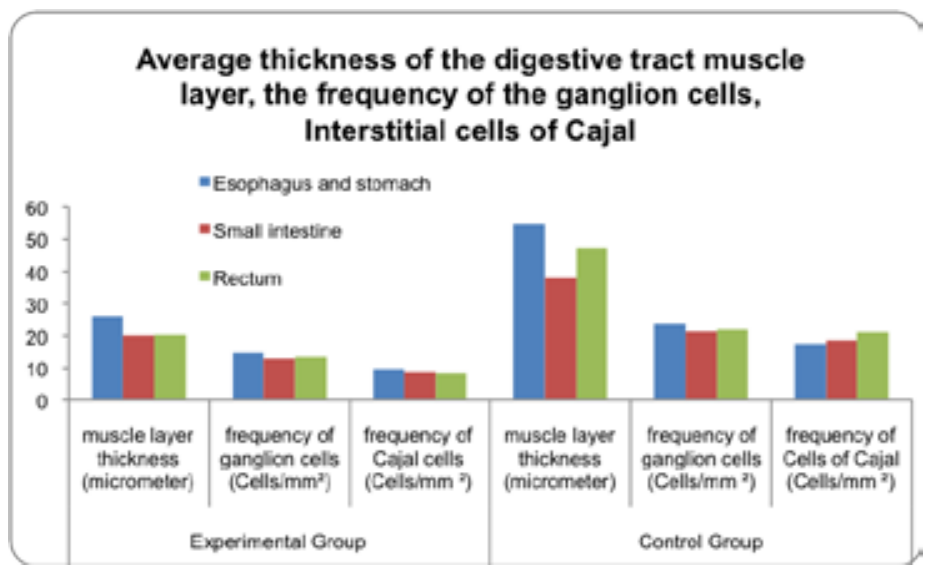

FIGURE 2 - Graph showing the average thickness of the digestive tract muscle layer, the frequency of the ganglion cells, Interstitial cells of Cajal.

\section{Immunohistochemical analysis}

An immunohistochemical analysis was performed with the aim of evaluating changes to the frequencies of ganglion cells and ICCs.

Evaluation by immunohistochemistry for neuro-specific enolase and protein S-100 (ganglion cells)

In the experimental group, it was observed that the frequency of ICCs was lower than in the control group. In the esophagus and stomach subgroup, the observed mean was 9.7 ( \pm 1.1) cells $/ \mathrm{mm}^{2}$ in the experimental group and $17.5( \pm 2.9)$ cells/ $\mathrm{mm}^{2}$ in the control group.

This pattern was also observed in the small intestine subgroups, with $8.6( \pm 1.1)$ cells $/ \mathrm{mm}^{2}$ (experimental group) and $18.6( \pm 1.8)$ cells $/ \mathrm{mm}^{2}$ (control group), and in the rectum subgroup, with $8.2( \pm 0.9)$ cells $/ \mathrm{mm}^{2}$ (experimental group) and $21.1( \pm 2.4)$ cells $/ \mathrm{mm}^{2}$ (control group) (Figure 3).

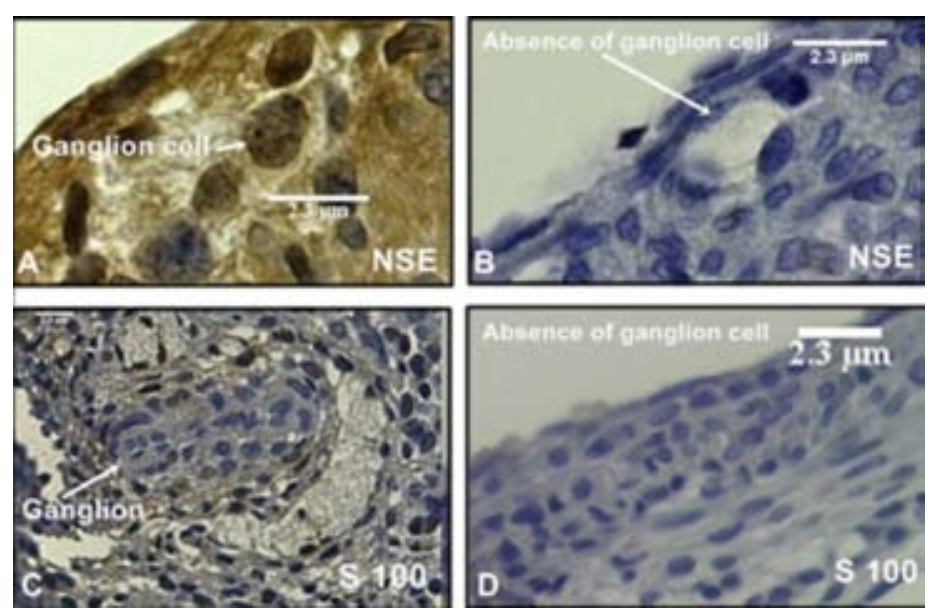

FIGURE 3 - Photomicrograph of cross-section through small intestine of a fetus rat. $\mathbf{A}$ and $\mathbf{C}-$ Neuron-specific enolase (NSE) and S-100 protein presenting ganglion cells; B and D - Neuron-specific enolase (NSE) and S-100 protein with absence of ganglion cells. Objective lens 100X.

\section{Evaluation by immunohistochemical c-kit or CD-117}

The ICCs were evaluated by means of immunohistochemistry using the C-Kit or CD-117 marker (Figure 4).

In the experimental group, it was observed that the frequency of ganglion cells was reduced in relation to the control group. In the esophagus and stomach subgroup, the observed measurements were $14.6 \pm 2.2$ cells $/ \mathrm{mm}^{2}$ for the rats exposed to ETU and $23.9 \pm 2.9$ cells $/ \mathrm{mm}^{2}$ for the controls. This pattern was also observed in the small intestine subgroups, with $12.9 \pm 1.4$ cells $/ \mathrm{mm}^{2}$ and $21.3 \pm 1.2$ cells $/ \mathrm{mm}^{2}$, and in the rectum subgroups, with $13.4 \pm 4.1$ cells $/ \mathrm{mm}^{2}$ and $21.9 \pm 2.3$ cells $/ \mathrm{mm}^{2}$, for the experimental and control groups respectively. 


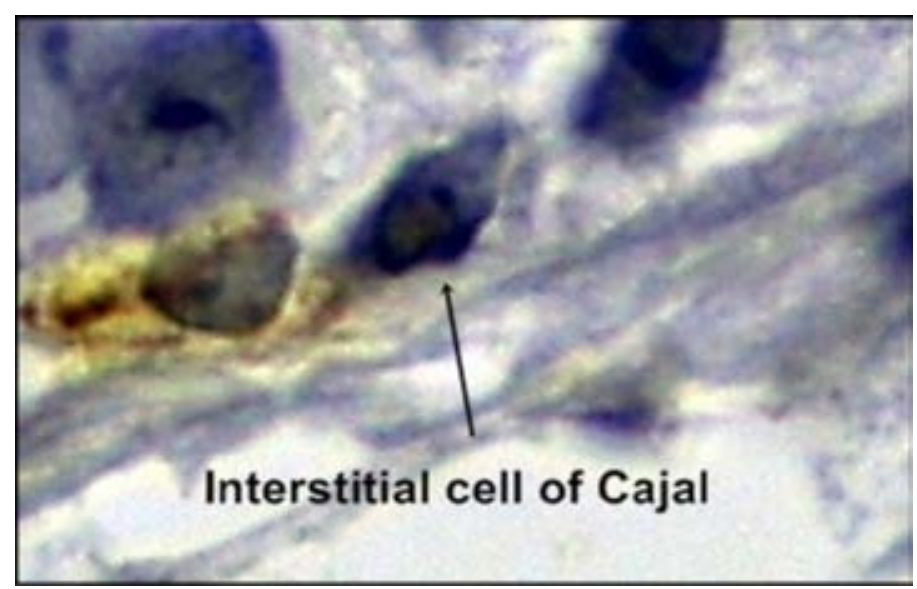

FIGURE 4 - Photomicrograph of cross-section through small intestine of rat in control group showing satellite and ganglion cells of the myenteric plexus that were positive for C-Kit or CD-117 markers. Objective lens $100 X$.

\section{Discussion}

There is a knowledge gap regarding abnormalities found in the nerve plexus of the digestive tract and their physiopathology in certain diseases, which makes it difficult to diagnose and treat these conditions and their complications.

Some abnormalities are related to changes in the myenteric system, such as anorectal anomalies particularly in the continent patients in which constipation frequently occurs ${ }^{6}$, the Hirschsprung's disease and dysganglionosis, among others.

It has been observed in humans that patients with dysfunctional intestinal transit present an association with abnormalities of the small intestine musculature ${ }^{5}$.

The relationship between anorectal anomalies and abnormalities of the myenteric plexus has been a matter of controversy among researchers who have investigated dysganglionosis following surgical treatment for anorectal anomalies. It has been suggested that such a relationship is one of the causes of postoperative intestinal constipation ${ }^{11}$.

ICCs have an important role in controlling intestinal motility, which includes generation of slow waves that are responsible for contractions of the smooth musculature of the intestine. Thus, they function as pacemakers in the gastrointestinal tract and as neurotransmission intermediaries in the enteric nerve system for smooth muscle cells ${ }^{12}$. Absence or reduction of the numbers or integrity of the ICCs may have a dramatic effect on gastrointestinal motility ${ }^{13}$.

These changes to the ICCs have been correlated with a variety of types of abnormality of intestinal motility, but the results are divergent ${ }^{14}$ and their understanding may promote advances in understanding intestinal motility ${ }^{13}$.

There is evidence that many disorders of gastrointestinal motility caused by neuron malformations are associated with concomitant changes to the ICCs. This observation may suggest that there is mutual influence between changes to the enteric nerve system and ICCs, during the development ${ }^{10}$.

The model studied here was shown to be easily reproducible, given that we found that 18 out of the 21 newborn rats $(86 \%)$ presented anorectal anomalies. The reproducibility rate was thus similar to the other authors, which ranged from $63.2 \%$ to $98 \%{ }^{16}$.

Abnormalities of the musculoskeletal system were presented in $100 \%$ of the experimental group. They were shown to be more severe in the pelvic limbs when in association with the absence of the tail and anorectal anomalies, and this was also described by Qi et al. ${ }^{16}$.

The spinal abnormalities found in the present study were similar to those found by other authors ${ }^{17}$. They occurred in $100 \%$ of the experimental group, which predominantly presented absence of the tail (15 of the 21 newborn rats; 71\%), while the other six animals (29\%) presented short or vestigial tails.

The analysis on the histological sections from the experimental group, with hematoxylin-eosin and immunohistochemical staining, clearly showed abnormalities of the myenteric plexus characterized by the absence of ganglion cells or by necrosis.

These changes occurred in the myenteric plexus throughout the gastrointestinal tract with similar intensities between the intestinal segments.

The present study made it possible to compare cell lesions relating to both ICCs and ganglion cells, in both the control and the experimental group, and to compare the control and experimental subgroups for the esophagus and stomach, small intestine and rectum.

The present study made it possible to compare cell lesions relating to both ICCs and ganglion cells, in both the control and the experimental group, and to compare the lesions in the different segments of the gastrointestinal tract.

The change to the frequency of ICCs found in the experimental subgroup for the rectum among the newborn rats with anorectal anomalies was 8.19 cells $/ \mathrm{mm}^{2}$, and the change to the frequency of ganglion cells was 13.35 cells $/ \mathrm{mm}^{2}$. These findings were similar to those of Macedo et al. ${ }^{8}$, and lower than those of Alberti et al. ${ }^{18}$ in the colon of a population of normal rats, and this difference may have occurred because of the increase in the number of cells that takes place from the neonatal phase to 
adult age ${ }^{19}$.

The changes in the myenteric plexus remained present also in the small intestine and stomach and esophagus of fetuses exposed to ethylenethiourea showing frequency of ICCs 8.6 and 9.7 cells $/ \mathrm{mm}^{2}$ and frequency of ganglion cells of 12.9 and 14.6 cells $/ \mathrm{mm}^{2}$ in the small intestine and stomach, and esophagus compared with the control group and 17.518 .6 cells / cells $/ \mathrm{mm}^{2}$ and 21.3 and 23.9 cells $/ \mathrm{mm}^{2}$ in the small intestine, stomach and esophagus, respectively, demonstrating that the changes in this model were not restricted to the pelvic region, but reaching the entire gastrointestinal tract similarly, showed that there was a statistically significant $(\mathrm{p}<0.01)$.

Comparing the reduction in frequency of $\mathrm{CIC}$ and ganglion cells between subgroups esophagus and stomach and small intestine and rectum, it was observed that the reduction occurred with similar intensity among the subgroups.

The comparison between experiment and control groups, showed significant difference in the thickness of muscle layer, showing the extent of $26.1 \mu \mathrm{m}, 20.1 \mu \mathrm{m}$ and $20.3 \mu \mathrm{m}$ in the esophagus and stomach, small intestine and rectum, respectively, compared with the control group measures $54.9 \mu \mathrm{m}, 37.9 \mu \mathrm{m}$ and $47.4 \mu \mathrm{m}$ in the esophagus and stomach, small intestine and rectum demonstrating that exposure to ETU induces abnormal development of the muscular layer of the digestive tract.

These changes were characterized by the thinner muscular layer of the digestive tract in the experimental group compared to controls.

Changes in muscle layers occurred in areas where injuries occurred in the myenteric plexus, suggesting that the drug has interfered in the formation of similar at both the muscular and nervous system, with intensity directly proportional to the myenteric plexus injury.

We observe an association between neuronal damage and changes of the muscles of the digestive tract, but it was not possible in this study determine whether changes occurred as a result of nerve changes in the muscle layer or vice versa, and can only observe that the ETU action interfered with the formation of anatomical normal, affecting the formation of intestinal segments during the embryonic period.

It was observed that Lesions in the muscle layer, of the ganglion cells, as well as the CICs, characterized by thinner intestinal muscles, were reduced in frequency of ICC and cells of the plexuses of Meissner and Auerbach, with similar intensity throughout the digestive tract, suggesting that lesions occurred with similar intensity throughout the gastrointestinal tract, with concomitant nerve injuries and muscle, impeding the adequate formation of the myenteric plexus and the intestinal muscles layer.

\section{Conclusions}

The fetuses exposed to ethylenethiourea changes in the myenteric plexus were associated with changes in the thickness of the muscle throughout the gastrointestinal tract.

There was a correlation between the intensity of the injury in intestinal smooth muscle and damage to the myenteric plexus throughout the gastrointestinal tract, showing that the more severe were the myenteric plexus injuries more severe were the injury intestinal muscles layer throughout the gastrointestinal tract.

\section{Reference}

1. Holschneider AM, Koebke J, Meier-Ruge W, Land N, Jesch NK, Pfrommer W. Pathophysiology of chronic constipation in anorectal malformations. Long-term results and preliminary anatomical investigations. Eur J Pediatr Surg. 2001;11:305-10.

2. Wang DJ, Bai YZ, Zhang SW, Gao H, Zhang SC, Zhang D, Zhang T, Yuan ZW, Wang WL. Expression of EphB2 in the development of anorectal malformations in fetal rats. J Pediatr Surg. 2009;44(3):5929.

3. Do MY, Myung SJ, Park HJ, Chung JW, Kim IW, Lee SM, Yu CS, Lee HK, Lee JK, Park YS, Jang SJ, Kim HJ, Ye BD, Byeon JS, Yang SK, Kim JH 1. Novel classification and pathogenetic analysis of hypoganglionosis and adult-onset Hirschsprungs disease. Dig Dis Sci. 2011;56(6):1818-27.

4. Reller MD, Strickland MJ, Riehle-Colarusso T, Mahle WT, Correa A. Prevalence of congenital heart defects in metropolitan Atlanta, 1998-2005. J Pediatr. 2008;153(6):807-13.

5. van den Berg MM, Di Lorenzo C, Mousa HM, Benninga MA, Boeckxstaens GE, Luquette M. Morphological changes of the enteric nervous system, interstitial cells of Cajal, and smooth muscle in children with colonic motility disorders. J Pediatr Gastroenterol Nutr. 2009;48(1):22-9.

6. Levitt MA, Kant A, Peña A. The morbidity of constipation in patients with anorectal malformations. J Pediatr Surg. 2010;45(6):1228-33.

7. Chen QJ, Jia HM, Niu ZX, Zhang T, Bai YZ, Yuan ZW, Wang WL. The development of satellite cells and their niche in striated muscle complex of anorectal malformations rat embryos. J Surg Res. 2011;168(1):e71-80

8. Macedo M, Martins JL, Meyer KF, Soares IC. Study of the density of ganglion cells in the terminal bowel of rats with anorectal malformations. Acta Cir Bras. 2007;22(6):441-5.

9. Blennerhassett MG, Vignjevic P, Vermillion DL, Collins SM. Inflammation causes hyperplasia and hypertrophy in smooth muscle of rat small intestine. Am J Physiol. 1992;262:G1041-6.

10. Wedel T, Spiegler J, Soellner S, Roblick UJ, Schiedeck TH, Bruch HP, Krammer HJ. Enteric nerves and interstitial cells of Cajal are altered in patients with slow transit constipation and megacolon. Gastroenterology. 2002;123:1459-67.

11. Raboei EH. Patients with anorectal malformation and Hirschsprung's disease. Eur J Pediatr Surg. 2009;19(5):325-7.

12. Han J, Zhou YP, Jiang YZ, He YT, Mei F. Postnatal development of interstitial cells of Cajal in mouse colon in response to Kit signal blockade with Imatinib (Glivec). Acta Histochem. 2010;112(3):21521. 
13. Mostafa RM. Interstitial cells of Cajal, the Maestro in health and disease. World J Gastroenterol. 2010;16(26):3239-48.

14. Miyahara K, Kato Y, Seki T, Arakawa A, Lane GJ, Yamataka A. Neuronal immaturity in normoganglionic colon from cases of Hirschsprung disease, anorectal malformation, and idiopathic constipation. J Pediatr Surg. 2009;44(12):2364-8.

15. Zhang SW, Bai YZ, Zhang SC, Wang DJ, Zhang T, Zhang D, Wang WL. Embryonic development of the striated muscle complex in rats with anorectal malformations. J Pediatr Surg. 2008; 43:1452-8.

16. Qi BQ, Beasley SW, Arsic D: Abnormalities of the vertebral column and ribs associated with anorectal malformations. Pediatr Surg Int. 2004;20(7):529-33.

17. Dan Z, Bo ZZ, Tao Z, Wei ZS, Jia WD, Cheng ZS, Wei YZ, Wang WL. Hoxd-13 expression in the development of hindgut in ethylenethiourea-exposed fetal rats. J Pediatr Surg. 2010;45(4):75561.

18. Alberti E, Mikkelsen HB, Larsen JO, Jimenez M. Motility patterns and distribution of interstitial cells of Cajal and nitrergic neurons in the proximal, mid- and distal-colon of the rat. Neurogastroenterol Motil. 2005;17(1):133-47.

19. Han J, Shen WH, Jiang YZ, Yu B, He YT, Li N, Mei F. Distribution, development and proliferation of interstitial cells of Cajal in murine colon: an immunohistochemical study from neonatal to adult life. Histochem Cell Biol. 2010;133(2):163-75.

\section{Correspondence:}

\section{Sidney Pereira Pinto Lemos}

Avenida Cardoso de Sá, 1175/401

56328-020 Petrolina - PE Brasil

Tel.: (55 87)3862-0346

sppls@hotmail.com

sidney_patricia@uol.com.br

Received: October 18, 2011

Review: December 14, 2011

Accepted: January 20, 2012

Conflict of interest: none

Financial source: none

${ }^{1}$ Research performed at Laboratory of Experimental Surgery, Federal University of San Francisco Valley (UNIVASF), Brazil.

Part of Master degree thesis. 